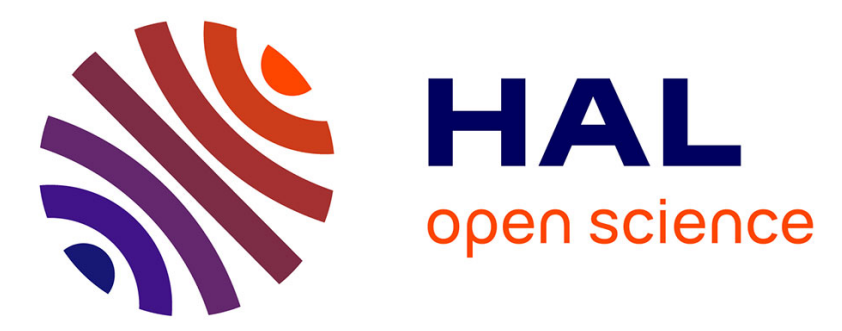

\title{
Development of 12 microsatellites loci for the longhorn beetle Monochamus galloprovincialis (Coleoptera Cerambycidae), vector of the Pine Wood Nematode in Europe
}

\author{
Julien Haran, Geraldine Roux-Morabito
}

\section{To cite this version:}

Julien Haran, Geraldine Roux-Morabito. Development of 12 microsatellites loci for the longhorn beetle Monochamus galloprovincialis (Coleoptera Cerambycidae), vector of the Pine Wood Nematode in Europe. Conservation Genetics Resources, 2014, 6 (4), pp.975-977. 10.1007/s12686-014-0262-0 . hal-02633851

\section{HAL Id: hal-02633851 \\ https://hal.inrae.fr/hal-02633851}

Submitted on 27 May 2020

HAL is a multi-disciplinary open access archive for the deposit and dissemination of scientific research documents, whether they are published or not. The documents may come from teaching and research institutions in France or abroad, or from public or private research centers.
L'archive ouverte pluridisciplinaire HAL, est destinée au dépôt et à la diffusion de documents scientifiques de niveau recherche, publiés ou non, émanant des établissements d'enseignement et de recherche français ou étrangers, des laboratoires publics ou privés. 


\title{
Development of 12 microsatellites loci for the longhorn beetle Monochamus galloprovincialis (Coleoptera Cerambycidae), vector of the Pine Wood Nematode in Europe.
}

\author{
Julien Haran \& Géraldine Roux-Morabito
}

INRA, UR633 Zoologie Forestière, 45075 Orléans Cedex 2, France

\begin{abstract}
Monochamus galloprovincialis (Coleoptera, Cerambycidae) is the vector of the Pine Wood nematode (Bursaphelenchus xylophilus) in Europe. This nematode is the agent of the Pine wild disease, a syndrome causing important damages in Eurasian pine forests. We report here the development of 12 polymorphic microsatellites loci specific to this species. We observed a moderate allelic richness over all loci. The number of allele per locus ranked from 2 to 8 , with an average of 3.75. These markers will help to characterize the effect of the spread of an invader on the genetic structure of a native vector species.
\end{abstract}

\section{Keywords}

Microsatellites; Monochamus galloprovincialis; Coleoptera; Cerambycidae; Pine Wood Nematode; Bursaphelenchus xylophilus; Europe.

The longhorn beetle Monochamus galloprovincialis (Coleoptera, Cerambycidae) is a widely distributed and native species in Europe. It performs its life cycle in the wood of stressed or freshly dead trees of the genus Pinus. This species has been recognized as the main vector involved in the spread of Pine Wood Nematode (PWN) Bursaphelenchus xylophilus, in Europe. The PWN is native to North America and has been introduced in several Eurasian countries. It is the agent of the Pine Wilt Disease, a syndrome causing important tree mortality in both plantations and natural pine ecosystems. The amount of dead trees generated by the invasion of the PWN is strongly affecting the population dynamics of M. galloprovincialis. This situation is a unique opportunity to study the effect of an alien spread on genetic structure of an associated native species. We developed a set of 12 microsatellites loci to identify changes in genetic structure of $M$. galloprovincialis involved by the invasion of the PWN.

Total genomic DNA was extracted from a leg using a Nucleospin ${ }^{\circledR}$ Kit (Macherey-Nagel, Düren, Germany) and sent to GenoScreen for development and optimization of microsatellites markers (www.genoscreen.fr). One mg of DNA was used for the development of microsatellite libraries through 454 GS-FLX Titanium pyrosequencing of enriched DNA libraries as described in Malausa et al. (2011). Total DNA was mechanically fragmented and enriched for AG, AC, AAC, AAG, AGG, ACG, ACAT and ATCT repeat motifs. PCR products were purified, quantified and GsFLX librairies were then carried out following manufacturer's protocols and sequenced on a GsFLX PTP. Sequences analysis and primer design were made using the software QDD (Meglécz \& Martin, 2009). A number of 386 loci were identified and 48 were selected for further assessment. Specificity and polymorphism assessment were tested using 14 individuals of $M$. galloprovincialis from various points of its whole distribution ranges. Among the 48 loci selected, 22 were validated as specific at one locus. Polymorphism was assessed on 18 loci and 12 were found to be polymorphic for the 14 individuals tested. A fluorescent dye (6'FAM, NED, PET VIC) was attached to $25 \%$ of the forward primer of each pairs for peaks discrimination. The 12 loci were grouped into 3 multiplexes.

Multiplexes conditions were validated in a $10 \mu \mathrm{L}$ PCR reaction volume using $25 \mathrm{ng}$ of genomic DNA, 0.4 U of DreamTaq DNA Polymerase (Thermo Scientific ${ }^{\circledR}$ ), $0.75 \mu \mathrm{L}$ Dream Taq 
Green Buffer (including $20 \mathrm{mM} \mathrm{MgCl} 2$, Thermo Scientific $\left.{ }^{\circledR}\right), 1 \mu \mathrm{M}$ Betaine, $0.24 \mu \mathrm{L}$ dNTP $(10 \mu \mathrm{M})$ and deionized $\mathrm{H}_{2} \mathrm{O}$. Detail of primers proportions of multiplexes is provided in Table 2. PCR amplifications were run on a Veriti ${ }^{\circledR} 96$ well fast Thermal cycler (Applied biosystems ${ }^{\circledR}$ ) using the following settings: a first denaturation step at $95^{\circ} \mathrm{C}$ during $10 \mathrm{~min} ; 40$ cycles of denaturation (30 sec at $\left.95^{\circ} \mathrm{C}\right)$, hybridization $\left(30 \mathrm{sec}\right.$ at $\left.55^{\circ} \mathrm{C}\right)$ and elongation $\left(1 \mathrm{~min}\right.$ at $\left.72^{\circ} \mathrm{C}\right)$; and a final elongation step at $72^{\circ} \mathrm{C}$ during $10 \mathrm{~min}$. One $\mu \mathrm{l}$ of PCR products were denatured within a mix of $10 \mu \mathrm{L}$ of formamide and $0,3 \mu \mathrm{L}$ of $600 \mathrm{Liz}$ marker before being analyzed using a (ABI PRISM 3500, Life Technologies ${ }^{\circledR}$ ). Genotypes were read using the software GeneMapper V 4.1 (Applied Biosystems ${ }^{\circledR}$ ).

Genetic parameters of the 12 microsatellites loci were calculated for one population from France (Orleans, $\mathrm{n}=30$ ). Deviation from Hardy-Weinberg equilibrium at each locus (Ho, He) and Fis were calculated using the software Genepop 4.2 (Raymon \& Rousset 1995). We used the software Genepop 4.2 (Raymon \& Rousset 1995) and a False Discovery Rate (FDR) correction (QVALUE, Storey et al. 2002) to test the presence of linkage disequilibrium in the set of loci. Null allele frequencies were estimated using the software Micro-checker (Van Oosterhout et al. 2004). The transferability of the 12 loci was tested on 3 congeneric European species: Monochamus sutor (Linnaeus), M. sartor (Fabricius), M. rosenmuelleri (Cederjelm) and on the Asian vector of the PWN (M. alternatus, Hope).

PCR of the 3 multiplexes gave positive results and the 12 loci could be amplified for all individuals tested. The genetic parameters are presented in Table 1. We observed a moderate allelic richness over all loci. The number of allele per locus ranked from 2 to 8 , with an average of 3.75 . No significant linkage disequilibrium was detected in this set of loci. An excess of homozygotes was found at locus Mon17, Mon27, Mon30 and Mon35, suggesting the presence of null alleles for those markers in the population studied. Cross priming assessment gave positive results for the 4 species tested (Table 2). At least 5 loci were fully or partially amplified for each species. M. sutor gave the best results, with 9 of the 12 loci amplified. The loci Mon 31, 36, 8 and 17 were fully or partially amplified for all the species.

\section{Acknowledgements}

This work was supported by the European project REPHRAME.

\section{References}

Malausa T, Gilles A, Meglécz E, Blanquart H, Duthoy S, Costedoat C, ... Martin JF (2011) High-throughput microsatellite isolation through 454 GS-FLX Titanium pyrosequencing of enriched DNA libraries. Molecular Ecology Resources, 11, 638-644.

Meglécz E, \& Martin JF (2009) QDD Version 1 A user-friendly program to select microsatellite markers and design primers from large sequencing projects. (online software) Raymond M \& Rousset F (1995) GENEPOP (version 1.2): population genetics software for exact tests and ecumenicism. J. Heredity, 86, 248-249. 
Storey JD (2002) A direct approach to false discovery rates. Journal of the Royal Statistical Society, Series B, 64, 479-498.

Van Oosterhout C, Hutchinson WF, Wills DPM, \& Shipley P (2004) Micro-checker: software for identifying and correcting genotyping errors in microsatellite data. Molecular Ecology Notes, 4, 535-538.

\section{Table captions:}

Table 1 : Details of loci characteristics and basic genetic parameters of the population tested (Orleans, France, $n=30$ ), including the multiplexing of primers "Multiplex" and relative amount of each primer "Amount". Na: number of alleles, Ho and He: observed and expected heterozygoties, Estimates of Fis values.

Table 2 : Transferability of the 12 loci developed for M. galloprovincialis. Values indicate the rate of positive amplification, N: number of individuls tested, " " " = no amplification. 


\begin{tabular}{|c|c|c|c|c|c|c|c|c|c|}
\hline Locus & Primers sequence $5^{\prime}$-> $\mathbf{3}^{\prime}$ & Multiplex & $\begin{array}{c}\text { Amount } \\
\text { (pmol) }\end{array}$ & Motif & Size range & $\mathrm{Na}$ & Ho & $\mathrm{He}$ & Fis \\
\hline \multirow[t]{2}{*}{ Mon 01} & F: TTCACGCACATCATTTCTTTG & 1 & 2.4 & (aac)5 & $122-146$ & 2 & 0.455 & 0.351 & -0.294 \\
\hline & R:TCAAGCAGGAAACGAAAAGC & & & & & & & & \\
\hline \multirow[t]{2}{*}{ Mon 08} & F: TGGTGTCTGTAGAACGCTTCA & 3 & 1 & (tatc)5 & 192-196 & 2 & 0.074 & 0.071 & -0.038 \\
\hline & R:GCTTATTAGCTCTCATCAGTATGCTC & & & & & & & & \\
\hline \multirow[t]{2}{*}{ Mon 17} & F: TAGTTTTACTGGGGCCAATG & 3 & 1.6 & (gt)6 & 149-153 & 3 & 0.286 & 0.487 & 0.413 \\
\hline & R:GAACTCATGAACGGATATAAATGAA & & & & & & & & \\
\hline \multirow[t]{2}{*}{ Mon 23} & F: ATTTATTCCAAАTTGCCAATACTACA & 1 & 2 & (ca)7 & $142-144$ & 2 & 0.379 & 0.307 & -0.234 \\
\hline & R:GTGTAAGGTGGAAGTGTCAAAGC & & & & & & & & \\
\hline \multirow[t]{2}{*}{ Mon 27} & F: ACAATCTCTTTCGATACCGTTGA & 3 & 2 & $(\operatorname{tg}) 7$ & $118-124$ & 4 & 0.167 & 0.517 & 0.677 \\
\hline & R:TTTGCTACAAAGATGTTCTTAAAAGT & & & & & & & & \\
\hline \multirow[t]{2}{*}{ Mon 30} & F: TTTCTAGTTTGCCTGTATCCCG & 1 & 1.6 & $(\mathrm{ag}) 8$ & $236-248$ & 4 & 0.133 & 0.340 & 0.608 \\
\hline & R:AAAGCGGGTGTGAAGTACCA & & & & & & & & \\
\hline \multirow[t]{2}{*}{ Mon 31} & F: GTAAGAGAACCCAACCACCG & 2 & 0.64 & (ag)8 & $146-150$ & 3 & 0.586 & 0.490 & -0.197 \\
\hline & R:TTATCCTCACCGGACCGTTA & & & & & & & & \\
\hline \multirow[t]{2}{*}{ Mon 35} & F: TTTCATCTGACTTAATTTTCTTTCTCA & 2 & 7.2 & (tc) 8 & $110-126$ & 8 & 0.519 & 0.784 & 0.339 \\
\hline & R:AGGGACGTGCAGATTAGGAA & & & & & & & & \\
\hline \multirow[t]{2}{*}{ Mon 36} & F: ACGGTGCAGAACTAAAGTTAGCC & 2 & 0.8 & $(\operatorname{tg}) 8$ & $196-200$ & 3 & 0.448 & 0.437 & -0.026 \\
\hline & R:GACTCGGACGGAGCTTCT & & & & & & & & \\
\hline \multirow[t]{2}{*}{ Mon 41} & F: ACGGTAGCGCAATCTTGAGT & 3 & 0.8 & $(c t) 9$ & $116-120$ & 3 & 0.200 & 0.209 & 0.045 \\
\hline & R:ACGTGAGCAGTCCTGTTGC & & & & & & & & \\
\hline \multirow[t]{2}{*}{ Mon 42} & F: CCTTATTTAGGTCAAGAATTCGC & 1 & 1.6 & (gt) 9 & $138-146$ & 5 & 0.586 & 0.627 & 0.065 \\
\hline & R:GCGTGTCATTATTCCAAGGAC & & & & & & & & \\
\hline \multirow[t]{2}{*}{ Mon 44} & F: AACCTGGACCTAGCTCGGAA & 2 & 0.64 & (act)10 & $98-113$ & 6 & 0.552 & 0.667 & 0.173 \\
\hline & R: TAGGAGAAGGTGGAGCAGGA & & & & & & & & \\
\hline
\end{tabular}

Table 1 : Details of loci characteristics and basic genetic parameters the population tested (Orleans, France, $\mathrm{n}=30$ ), including the multiplexing of primers "Multiplex" and relative amount of each primer "Amount". Na: number of alleles, Ho and He: observed and expected heterozygoties, Estimates of Fis values. 
Microsatellite loci

\begin{tabular}{|c|c|c|c|c|c|c|c|c|c|c|c|c|c|}
\hline \multirow[b]{2}{*}{ Species } & \multirow[b]{2}{*}{$\mathbf{N}$} & \multirow{2}{*}{\multicolumn{3}{|c|}{$\begin{array}{lll}01 & 23 & 30\end{array}$}} & \multirow[b]{2}{*}{42} & \multirow{2}{*}{\multicolumn{2}{|c|}{$31 \quad 35$}} & \multirow{2}{*}{\multicolumn{2}{|c|}{$36 \quad 44$}} & & \multirow[b]{2}{*}{41} \\
\hline & & & & & & & & & & 08 & 17 & 27 & \\
\hline M. sutor & 26 & - & 100 & 11 & - & 100 & 23 & 100 & - & 42 & 88 & 19 & 11 \\
\hline M. sartor & 4 & - & - & 75 & - & 100 & - & 100 & 100 & 100 & 100 & - & - \\
\hline M. rosenmuelleri & 2 & - & - & 100 & 100 & 100 & - & 100 & 100 & 100 & 100 & 100 & - \\
\hline M. alternatus & 2 & - & - & 100 & - & 100 & _ & 50 & - & 100 & 100 & 100 & - \\
\hline
\end{tabular}

Table 2 : Transferability of the 12 loci developed for M. galloprovincialis. Values indicate the rate of positive amplification, " " $=$ no amplification, N: number of individuls tested. 